\title{
Deglacial landform assemblage records fast ice-flow and retreat, Inner Hebrides, Scotland D. DOVE $E^{1 *}$, A. FINLAYSON ${ }^{1}$, T., BRADWELL ${ }^{1,2}$, J. A. HOWE ${ }^{3}$ \& R. AROSIO ${ }^{3}$ \\ ${ }^{1}$ British Geological Survey, Murchison House, West Mains Road, Edinburgh, EH9 3LA, UK. \\ ${ }^{2}$ Biological and Environmental Sciences, University of Stirling, Stirling, FK9 4LA, UK; \\ ${ }^{3}$ Scottish Association for Marine Science, Scottish Marine Institute, Oban, PA37 1QA, UK. \\ *Corresponding author (e-mail: dayt@bgs.ac.uk)
}

High-resolution bathymetry data have been central to many recent advances in the understanding of past dynamics of the former British-Irish Ice Sheet (BIIS). As approximately two thirds of the former BIIS was probably marine-based during the Last Glacial Maximum (LGM) ( 29-23 ka), geomorphic observations of the seabed are increasingly required to understand the extent, pattern, and timing of past glaciation. Until recently, glacial reconstructions for the Inner Hebrides, offshore western Scotland, have been based primarily on terrestrial observations and data. Previous workers have proposed generalised reconstructions in which the Inner Hebrides are located within a significant former ice-sheet flow pathway that drained the western Scottish sector of the BIIS, feeding the Barra Fan during the LGM and earlier glaciations (Fig. 1). Results from numerical ice-sheet modelling suggest that former ice-flow velocities within the region were on the order of hundreds to thousands of metres per year, but also yield further insight by demonstrating how dynamic binge/purge cycles affected ice-sheet mass balance over time (Hubbard et al. 2009). Following the LGM, ice-sheet retreat through the area is estimated to have been in the order of $20 \mathrm{~m}$ per year (Clark et al. 2012). Here we present swath bathymetry data from the Inner Hebrides that provide in situ constraints on the ice-sheet flow, and subsequent retreat dynamics from within this important sector of the BIIS.

\section{Description}

Within the Inner Hebrides (Fig 1a.), Howe et al. (2012) used high-resolution swath bathymetry to identify the first direct evidence relating to subglacial processes and fast ice-flow on the inner shelf. These data have been compiled together with newer bathymetry, as well as terrestrial airborne radar data, to form a near-continuous offshore-onshore digital elevation model (DEM) (horizontal resolution - $5 \mathrm{~m}$ ) that covers the majority of the Inner Hebrides region (Dove et al. 2015). These data cover an extensive an area $\left(\sim 7,000 \mathrm{~km}^{2}\right)$, and our interpretation of the style, location, and pattern of glacial landform assemblages reveals new evidence on the configuration and relative timing of past phases of ice-sheet flow and retreat in the region.

On multiple submarine rock platforms and within overdeepened troughs, a diverse assemblage of streamlined ridges and elongate landforms oriented broadly parallel, or sub-parallel to major basin axes is observed (Figs. 1, 2). These streamlined landforms occur in areas of both bedrock and unlithified sediment and are up to several kilometres in length. Sedimentary features range in height up to $20 \mathrm{~m}$, with elongation ratios between 2:1 and 10:1. Streamlined landforms comprising some 
bedrock component may be up to $50 \mathrm{~m}$ in height, with elongation ratios commonly exceeding 10:1, although this may be enhanced by structural trends in the underlying bedrock.

In some areas, sets of streamlined elongate ridges are found to be superimposed on one another and, in some cases, convergent. In one area, two distinct sets of streamlined landforms are observed, and a dominantly SW-directed ridge set is superimposed by a later, less extensive SSW-directed set (Fig. 1b). In addition, south of Tiree, a set of southerly-directed ridges converges on a larger set of streamlined landforms with a SW bearing (Fig. 1c). Further inshore, aggregations of streamlined landforms are found within more topographically controlled, fjord-type settings, such as the Sound of Jura (Fig. 2a).

A number of other sediment ridges are also observed, frequently overprinting the streamlined landforms (Figs. 1c, 2a). These long, narrow ridges (up to about $8 \mathrm{~km}$ long, typically $5 \mathrm{~m}$ high, and 25 to $100 \mathrm{~m}$ wide) with an irregular planform, are typically arranged approximately orthogonal to the underlying streamlined landforms, and transverse to the main basin axis and/or adjacent coastline. These transverse ridges are relatively regularly spaced, with smaller, sub-parallel ridges distributed between the larger ridges (Fig. 2, inset).

\section{Interpretation}

The swath-bathymetry data described above reveal submarine evidence of glaciation relating to the last glacial cycle (Dove et al. 2015). Here we emphasize the close association between streamlined landforms, which are interpreted to have formed beneath fast-flowing ice, and overprinting transverse ridges deposited during deglacial ice-margin retreat. The Hebrides Ice Stream, whose presence is inferred from the streamlined and highly elongate submarine landforms, appears to have extended from the western margin of the Inner Hebrides out onto the Malin Shelf, ultimately feeding the Barra trough-mouth fan approximately $150 \mathrm{~km}$ to the west (Fig. 1).

The elongate and streamlined landforms, comprising sedimentary and bedrock drumlins, crag-andtails, and mega-flutes, are interpreted to have been produced subglacially. Previous studies have shown that these subglacial landforms are elongated parallel to the flow direction of palaeo icemasses on mid- to high-latitude shelves (Figs. 1, 2) (Stokes \& Clark 2001; Ottesen et al. 2005). Apart from the subglacial-formation principles governing the size, shape, and spacing of streamlined landforms (e.g. Fowler et al. 2013), their local distribution within the Inner Hebrides depends on several further factors. These factors include their relative physiographic position (e.g. within overdeepened troughs or fjords), the presence of bedrock at or near the seafloor, and preservation potential (e.g. reworking by wave action and tidal currents in shallow water, or burial by subsequent sedimentation). $\mathrm{G}$ landforms in the submarine environment must also be distinguished from hydrodynamically-controlled features like mobile sedimentary bedforms (Fig 1c).

We interpret the streamlined landforms features to have formed beneath a large ice-stream system, probably within the transition zone between slower 'sheet flow' and faster 'streaming flow' as ice flowed from the more rugged Scottish hinterland (Bradwell 2013), and accelerated out towards the open Malin Shelf where a sedimentary rather than bedrock substrate dominates the seabed (Fig. 1a). As originally proposed by Howe et al. (2012), landforms attributed to this 'onset zone' are distributed across a geographically-controlled area, semi-independent of the region's complex bedrock geology (Dove et al. 2015).

Where two differently oriented sets of subglacial landforms are superimposed, they are interpreted to represent two distinct stages of glacier flow (Fig. 1b). This cross-cutting assemblage suggests ice- 
sheet reorganization over time, with different phases of fast flow at the ice-sheet bed (e.g. Stokes et al. 2009). The preservation of both subglacial landform sets at the seabed implies there was no further broad-scale incursion of ice across the region, suggesting that the preserved record of flow is associated with overall ice-sheet wastage.

The convergence of flow sets demonstrates that ice-sheet drainage within the onset zone was also organized into corridors of slower and faster flowing ice. For example, the streamlined landforms in Figure 1c indicate that the ice sheet did not flow directly west across the low-relief topography of Tiree (towards the outer shelf), but rather was drawn into a larger branch of SW-directed flow. This larger trunk of flow probably extended at least $20 \mathrm{~km}$ to the southeast (Fig. 1b).

Swath-bathymetry data from the Sound of Jura, a glacially overdeepened fjord-like basin 'up-glacier' from the postulated onset zone of the Hebrides Ice stream, is shown in Figure 2. We interpret an assemblage of streamlined landforms to be characteristic of the coherent flow of an overriding ice mass. Unlike the previous examples, the streamlined landforms in the Sound of Jura are more strongly topographically controlled, mimicking the large-scale physiography of the trough. In this geographic position during full-glacial conditions, ice-sheet flow would have been more westerly directed than recorded in the streamlined submarine landforms. Evidence of this more westerly flow regime is observed on bedrock at higher elevations on the nearby islands of Islay and Arran where glacial evidence is found to summit level (e.g. Finlayson et al. 2014). The more confined flow described here is indicative of a thinner ice-mass governed significantly by local topography. This scenario is more consistent with formation during overall ice-sheet retreat, probably following collapse of the Hebrides ice stream, as the ice sheet pulled back into smaller tributaries and fjords.

The transverse-to-flow ridges superimposed on the elongate subglacial landforms are interpreted as moraines, deposited during ice-margin retreat, and suggest retreat to the northeast, normal to ridge orientation (Fig. 1c). As these moraines are predominantly normal to the underlying streamlined landforms, and are remarkably well-preserved at the seabed, we suggest that the ice margin retreated (perhaps quickly) to this location not long after the cessation or breakup of the Hebrides Ice Stream.

Following this logic, we suggest that the recessional moraines within the Sound of Jura were also deposited soon after ice streaming ceased (Fig. 2a). The series of minor transverse ridges between the larger recessional moraines appear similar in form and spacing to De Geer moraines (Fig. 2 inset) (Todd et al. 2007), which would indicate sub-aqueous deposition. This, together with the convex 'upglacier' inclination across the trough, and the over-deepened bathymetry of the Sound of Jura, suggests that ice-sheet retreat occurred at a tidewater margin, grounded in relatively shallow water, but with floating ice shelves perhaps extending over deeper water (Fig. 2b) (Ottesen \& Dowdeswell 2006).

\section{Discussion: landform assemblage around the Inner Hebrides, Scotland}

The submarine landform-assemblage around the Inner Hebrides includes elements relating to fast icesheet flow and ice-margin retreat. Strongly streamlined glacigenic landforms orientated predominantly parallel to former ice flow are characteristic of palaeo-ice streams, whereas transverseto-flow landforms generally relate to the deglacial retreat of a grounded ice margin (Ottesen \& Dowdeswell 2009). Our reconstruction highlights (i) fast-flow of grounded ice probably within an ice stream onset zone with periods of ice-sheet reorganisation and ultimately, ice-stream collapse, followed by (ii) ice-sheet retreat into topographically controlled fjords where deglaciation proceeded along tidewater margins. Modern analogues of these landform associations can be found in Antarctica (King et al. 2007) and Svalbard (Ottensen \& Dowdeswell 2006). 
The occurrence and configuration of streamlined submarine landforms around the Inner Hebrides indicates grounded, coherent flow of the BIIS during regional-scale ice-streaming events. Streamlined landforms on the western margin of the Inner Hebrides are attributed to the onset zone of the Hebrides ice stream (Figs. 1b,c). Cross-cutting subglacial landforms indicate glacier reorganization during what was probably a punctuated retreat from the shelf (Dowdeswell et al. 2008). Following the deactivation of the Hebrides Ice Stream, ice margins retreat, and recessional moraines were deposited and preserved on several of the region's bedrock highs (Fig. 1c). This overprinting of transverse moraines upon a glacially-streamlined landscape further supports a deglacial setting for the landform assemblage (Dove et al. 2015).

The geomorphic observations presented here are broadly consistent with the spatial reconstructions and event timescale proposed by Finlayson et al. (2014). Under this model the Hebrides Ice Stream was active approximately 32-17 ka, though with significant fluctuations in mass-flux and spatial extent over time. Rather than being formed during maximal glacial conditions ( 29-23 ka), the configuration of streamlined glacial landforms (e.g. cross-cutting flow sets, convergent flow indicators (Fig. 1)) is more indicative of formation beneath an ice mass undergoing reorganization during overall ice-sheet retreat (Dove et al. 2015). The preservation of these landforms at the seabed suggests they represent the last regional-scale ice-streaming event from the Inner Hebrides towards the outer shelf. As the ice stream diminished, becoming inactive around 17-16.5 ka (Finlayson et al. 2014), ice-sheet margins retreated to the topographically confined fjords and basins where further flow was recorded (Fig 2). Further decay, and final ice-sheet retreat from the marine environment was likely achieved within these fjords along partially grounded tidewater margins between approximately $16.5 \mathrm{ka}$ and $16 \mathrm{ka}$ (Fig. 2b).

\section{References}

BRADWELL, T. 2013. Identifying palaeo-ice-stream tributaries on hard beds: mapping glacial bedforms and erosion zones in NW Scotland. Geomorphology, 201: 397-414.

CLARK, C. D., HUGHES, A. L. C., GREENWOOD, S. L., JORDAN, C., \& SEJRUP, H. P. 2012. Pattern and timing of retreat of the last British-Irish Ice Sheet. Quaternary Science Reviews, 44, 112-146.

DOVE, D., FINLAYSON, A., BRADWELL, T., AROSIO, R. \& HOWE, J. A. (2015). Submarine glacial landforms record Late Pleistocene ice-sheet dynamics, Inner Hebrides, ScotlandQuaternary Science Reviews, 123, 76-90.

DOWDESWELL, J. A., OTTESEN, D., EVANS, J., Ó COFAIGH, C. \& ANDERSON, J. B. 2008. Submarine glacial landforms and rates of ice-stream collapse. Geology, 36, 819-822.

FINLAYSON, A., FABEL, D., BRADWELL, T. \& SUGDEN, D. 2014. Growth and decay of a marine terminating sector of the last British-Irish Ice Sheet: a geomorphological reconstruction. Quaternary Science Reviews, 83, 28-45.

FOWLER, A. C., SPAGNOLO, M., CLARK, C. D., STOKES, C. R., HUGHES, A. L. C. \& DUNLOP, P. 2013. On the size and shape of drumlins.. GEM-International Journal on Geomathematics, 4, 155-165.

HOWE, J. A., DOVE, D., BRADWELL, T. \& GAFEIRA, J. 2012. Submarine geomorphology and glacial history of the Sea of the Hebrides, UK. Marine Geology, 315, 64-76.

HUBBARD, A., BRADWELL, T., GOLLEDGE, N., HALL, A., PATTON, H., SUGDEN, D., COOPER, R. \& STOKER, M. 2009. Dynamic cycles, ice streams and their impact on the extent, chronology and deglaciation of the British-Irish ice sheet. Quaternary Science Reviews, 28, 758-776.

KING, E. C., WOODWARD, J. \& SMITH. A. M. 2007. Seismic and radar observations of subglacial bed forms beneath the onset zone of Rutford Ice Stream, Antarctica. Journal of Glaciology, 53, 665-672.

OTTESEN, D. \& DOWDESWELL, J. A. 2006. Assemblages of submarine landforms produced by tidewater glaciers in Svalbard. Journal of Geophysical Research, 111, doi:10.1029/2005JF000330

OTTESEN, D. \& DOWDESWELL, J. A. 2009. An inter-ice stream glaciated margin: submarine landforms and a geomorphic model based on marine-geophysical data from Svalbard. Geological Society of America Bulletin, 121, 16471665.

OTTESEN, D., DOWDESWELL, J. A. \& RISE, L. 2005. Submarine landforms and the reconstruction of fast-flowing ice streams within a large Quaternary ice sheet: the 2500 -km-long Norwegian-Svalbard margin $\left(57^{\circ}-80^{\circ} \mathrm{N}\right)$. Geological Society of America Bulletin 117, 1033-1050.

STOKES, C .R., \& CLARK, C. D. 2001. Palaeo-ice streams. Quaternary Science Reviews, 20, 1437-1457.

STOKES, C. R., CLARK, C. D., \& STORRAR, R. 2009. Major changes in ice stream dynamics during deglaciation of the north-western margin of the Laurentide Ice Sheet. Quaternary Science Reviews, 28, 721-738. 
TODD, B. J., VALENTINE, P. C., LONGVA, O. \& SHAW, J. 2007. Glacial landforms on German Bank, Scotian Shelf: evidence for Late Wisconsinan ice-sheet dynamics and implications for the formation of De Geer moraines. Boreas, 36, 148-169.

\section{Figure Captions:}

Fig. 1. Swath-bathymetric images from the (a) Inner Hebrides, Scotland (acquired with both multibeam and interferometric systems for the Maritime and Coastguard Agency's UK Civil Hydrography Programme (C) Crown copyright.; grid-cell size 5 m resolution). (b) Superimposed flow sets of streamlined landforms. Landforms associated with black flow arrows post-date features associated with white arrows. (c) Convergence zone of two ice stream tributaries overlain by a series of recessional moraines indicating later ice margin retreat to the NE. Inset shows interpreted glacigenic landform map highlighting key seabed features. Terrestrial airborne radar data from Intermap Technologies NEXTMap Britain elevation data.

Fig. 2. (a) Bathymetry, and terrestrial airborne radar data provide a near-continuous DEM in and around the Sound of Jura; grid-cell $5 \mathrm{~m}$. Inset at top left illustrates a series of recessional moraines and minor transverse ridges which record ice-sheet retreat to the north, overprinting streamlined landforms associated with previous ice streaming. Together, all glacigenic landforms are superimposed on the pronounced bedrock fabric expressed at the seabed. Inset at bottom right shows interpreted geomorphological map which highlights the configuration of key landforms (b) Conceptual reconstruction (oblique view) of the retreating tidewater ice margin, looking north up the Sound of Jura, and overlain on the high-resolution DEM (VE x 3). 

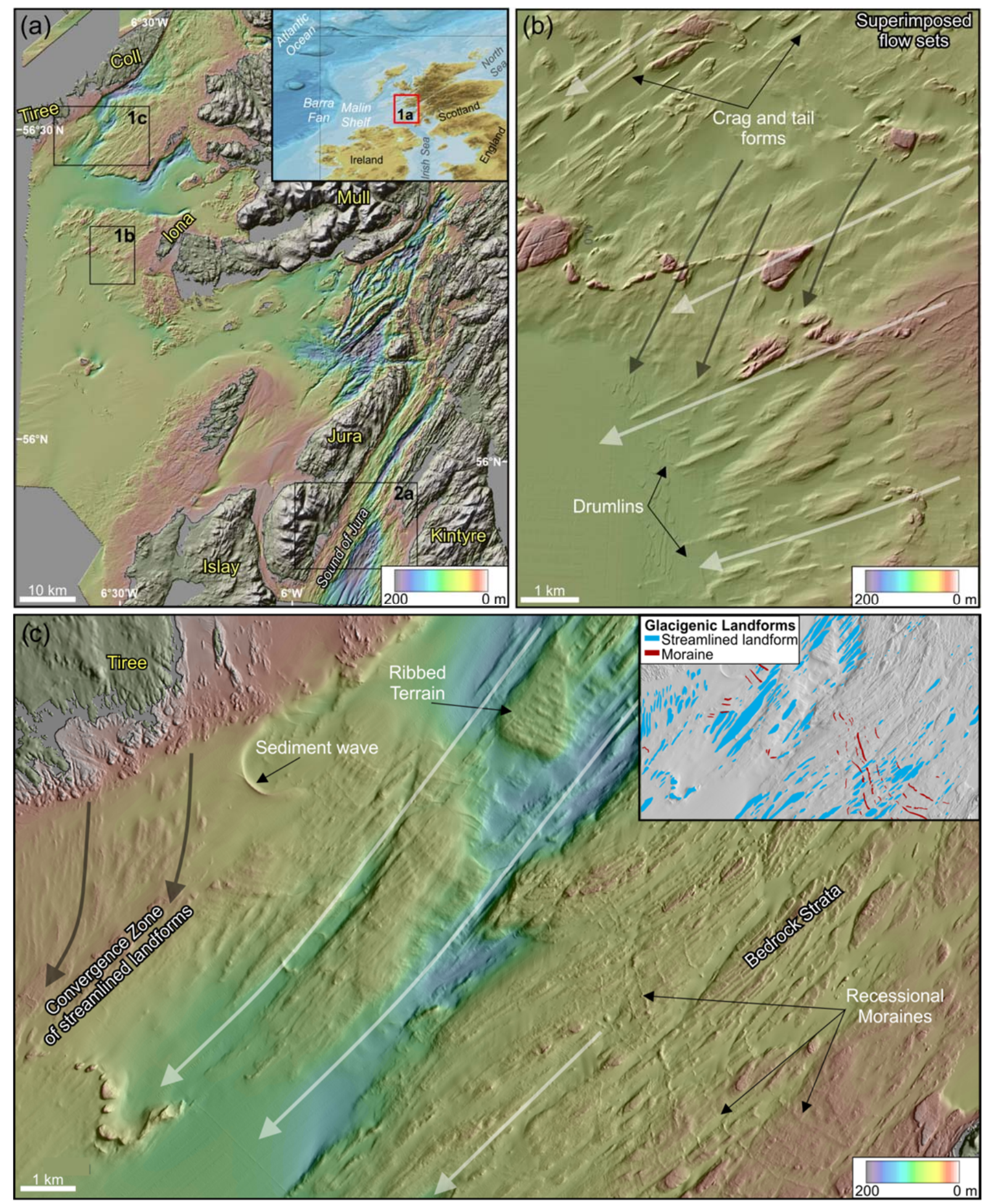

Fig. 1 

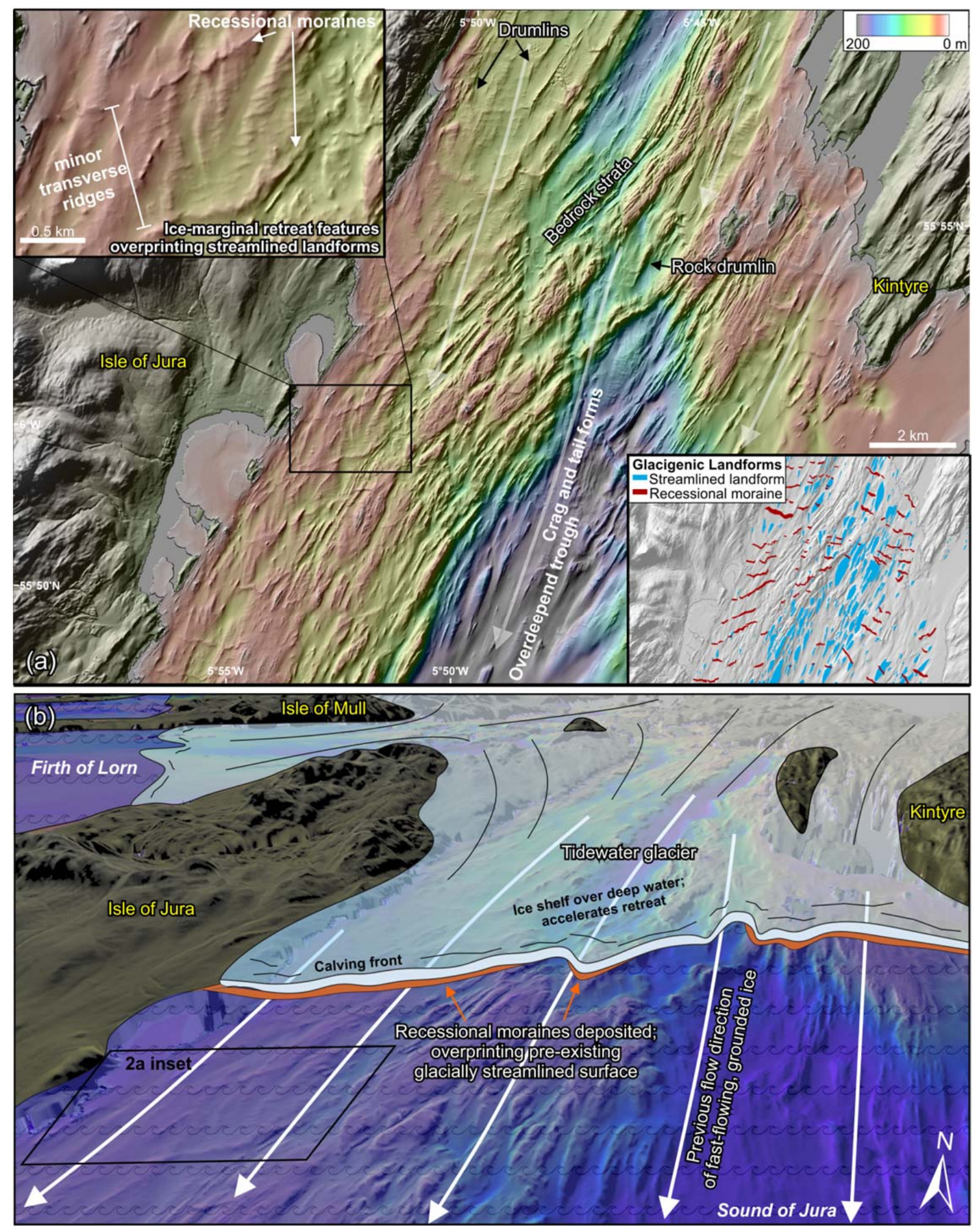

Fig. 2 